Dyuzhev, V.G., and Boichenko, O.I.

Kharkiv Polytechnic Institute, National Technical University,

2, Kirpichova St., Kharkiv, 61002, Ukraine,

+380501842823, olegmet3000@ukr.net

\title{
INFLUENCE OF CORPORATE SOCIAL NETWORKS ON THE INNOVATIVE RECEPTIVITY OF PERSONNEL, BY EXAMPLE OF BITRIX24 SOFTWARE (VO OVEN Ltd.)
}

\footnotetext{
Introduction. Increasing the innovative receptivity (IR) of personnel using intra-corporate social networks (CSN) is a pressing problem.

Problem Statement. Currently, Ukraine is actively discussing the problems of digital transformations in the economy, as well as the importance of digital initiatives and research in this industry, as evidenced by the Conception for the development of the digital economy and society of Ukraine for 2018-2020 and a respective action plan for the implementation of this Conception (approved by the Cabinet of Ministers of Ukraine) adopted in January 2018. Theoretical and practical issues of analyzing the impact of intra-corporate communications in the CSN on the development of competencies and IR of employees have not been fully developed so far.
}

Purpose. To identify trends and effect of CSN on personnel IR by example of Bitrix24 software in VO OVEN Ltd.

Materials and Methods. Methods for comparative analysis of local and international CSN operation in Ukraine and throughout the world; analysis of the use of Bitrix24 software in the Ukrainian company.

Results. The ways to increase the IR of personnel using CSN and classic Internet portal have been shown. The CSN services in the system of corporate business tasks and their authentication with conventional human resources management system have been analyzed. The domains of effective CSN application in American corporations and in VO OVEN Ltd (Ukraine) have been compared. Data summary of Bitrix24 information messages (live news feed) in VO OVEN Ltd for 2017 and for the $1^{\text {st }}$ quarter of 2018 has been given. Based on research results, a new HRMS function has been implemented to show the dataware of personnel and the realization of technical and economic processes for developing CSN under current conditions.

Conclusions. To ensure an adequate perception of digital technologies on industrial corporations, Ukraine needs highly qualified personnel with digital skills and competences. One of the options to develop these competences is to use CSN.

Keywords: innovative receptivity, corporate social networks, and Bitrix24.

Today, the topical issue of increasing the innovative receptivity (IR) of personnel is the use of in-house communications in corporate social networks (CSN) that are an information computer system based on special software systems. This creates a new communicative environment within the corporation based on the chosen system, which is designed to control receiving, analyzing, and transmitting information between

(c) DYUZHEV, V.G., and BOICHENKO, O.I., 2019 its various subsystems and subjects (users). However, the theoretical and practical issues of analyzing the impact of in-house communications in the CSN on the development of competencies and IR of the personnel have not been fully developed. In order to enhance IR and to raise the efficiency of the personnel innovation activities, it is necessary to estimate the effectiveness and influence of intra-company communications on IR of structural units and individual employees. 
As a means of solving this problem, a model for analyzing and developing the interrelated factors of IR of employees and managers based on their activity in the CSN has been considered. The use of in-house CSN enables to connect the information and operational capabilities of software and computer systems with the actual sets of information and communication relationships and interactions of corporation's employees. This makes it possible to speed up information flows, to quickly analyze relevant information, and to take necessary management procedures, which ultimately (due to a high speed of adaptive structuring, rapid processing, conversion, distribution, and feedback) enables to increase IR of both individual employees, specific departments, and corporation's staff as a whole [1].

In order to be able to use CSN for the sake of corporations and to establish their distinction from the Internet portals, the former has been classified in Table 1 below.

It is necessary to pay attention towards the CSN structure, purposes, and objectives for raising IR in terms of corporate governance and human resources management. Consequently, it is necessary to consider the services of corporate social applications in the context of addressing business tasks of the corporation (Table 2) [3].

In world practice, all types of the above mentioned local CSN have been used. The choice of certain types of networks dependi on tasks, scale, and nature of their use in the corporate information field of organizations. For example, in-house Bitrix24 system is a universal portal for various applications, which enables to carry out a certain type of activity depending on the settings and customization. Its main features are strong project management, operations with files and docu-

CSN Classification and Their Use Patterns [2]

Table 1

\begin{tabular}{|c|c|c|}
\hline $\mathrm{CSN}$ & Typical characteristics & Use patterns \\
\hline Bitrix 24 & $\begin{array}{l}\text { Intranet with separate social } \\
\text { module }\end{array}$ & $\begin{array}{l}\text { The module contains functions for microblogging, messenger, photo gallery, } \\
\text { etc. The interface and application functionality is a bit like social networks } \\
\text { of the early 2000s. The social application is free, but it does not work until } \\
\text { the basic package Bitrix } 24 \text { is purchased. The cost depends on the selected } \\
\text { plan and the number of employees, as well as on the implementation option: } \\
\text { the version for installation on the server costs higher than the cloud one }\end{array}$ \\
\hline DaOffice & $\begin{array}{l}\text { The first Russian corporate } \\
\text { social network. As compared } \\
\text { with Bitrix } 24 \text {, it is more con- } \\
\text { centrated on social tools }\end{array}$ & $\begin{array}{l}\text { Microblogs support \#tags and @names like Troitter, enables to "like" favorite } \\
\text { posts, to see a list of recommended friends, like in Facebook. A distinctive } \\
\text { feature is elements of gamification: for posting messages on relevant and use- } \\
\text { ful topics, the employees score points. Access to DaOffice is possible from } \\
\text { mobile devices using Android and } i O S \text { applications. The cost of installation is } \\
\text { determined specifically for each company and depends on the Team version } \\
\text { (a full-fledged corporation's own CSN) or Enterprise (maximum functional- } \\
\text { ity for deep integration of social mechanics into the corporation's business } \\
\text { processes), implementation options (server or cloud), the need for interoper- } \\
\text { ability and additional options. The free version is available only for large } \\
\text { companies (more than } 250 \text { employees). Restrictions on administration tools } \\
\text { appear when installed on corporate server. }\end{array}$ \\
\hline Jive & $\begin{array}{l}\text { Intranet with social func- } \\
\text { tions }\end{array}$ & $\begin{array}{l}\text { Jive users can customize their individual workspace. The application con- } \\
\text { tains tools for managing tasks, corporate content and projects. Jive is avail- } \\
\text { able for mobile devices and is interoperable with Office } 365 \text { and Google prod- } \\
\text { ucts. The cost depends on the package: Select, Premier or Premier }+ \text {. A serious } \\
\text { disadvantage is the lack of a Russified version. In addition, according to cus- } \\
\text { tomer reviews, navigation in Jive is very different from the usual navigation } \\
\text { in social networks }\end{array}$ \\
\hline
\end{tabular}




\begin{tabular}{|c|c|c|}
\hline $\mathrm{CSN}$ & Typical characteristics & Use patterns \\
\hline Yammer & $\begin{array}{l}\text { The world most popular so- } \\
\text { cial Intranet }\end{array}$ & $\begin{array}{l}\text { Available to users as part of Office } 365 \text {. The structure is similar to that of } \\
\text { Troitter, allowing employees to share short messages, to form working groups } \\
\text { and to monitor the "status" of subordinates. Other features of the service } \\
\text { include exchanging files and images, supporting tags in messages, viewing } \\
\text { online contacts, searching for people, groups and texts, creating and using } \\
\text { the knowledge base. Support of } 25 \text { languages, no language barrier. Since } \\
\text { Yammer became part of the Office } 365 \text { online office, it could not be installed } \\
\text { separately. Another significant drawback is the lack of on premise option, } \\
\text { only a cloud (off premise) solution with servers located abroad is available }\end{array}$ \\
\hline $\begin{array}{l}\text { Facebook } \\
\text { Workplace }\end{array}$ & $\begin{array}{l}\text { Corporate social network as } \\
\text { it is }\end{array}$ & $\begin{array}{l}\text { Very similar to the classic version of Facebook. At the same time, the user } \\
\text { profiles are not linked to their FB accounts. The same tools, including news } \\
\text { lines, personal profiles, groups, chats, presentations, video calls are available. } \\
\text { The main advantage of Facebook Workplace is its familiar interface that does } \\
\text { not require any retraining. The product is intended for large corporations, } \\
\text { with its cost depending on the size of corporation. If the number of employees } \\
\text { in a corporation is less than } 1000 \text { people, the cost is about USD } 3 \text { per } \\
\text { employee; if it ranges between } 1,000 \text { and } 10,000 \text { people, the cost is USD } 2 . \text { A } \\
\text { free three-month trial period is provided. The main disadvantages are the } \\
\text { lack of customization and on premise option. Only cloud version is available } \\
\text { with servers located abroad }\end{array}$ \\
\hline CyberCloud & $\begin{array}{l}\text { Enables creating a full-fled- } \\
\text { ge CSN with a complex func- } \\
\text { tionality }\end{array}$ & $\begin{array}{l}\text { Enables to create news, personal messages, shared files, a common knowledge } \\
\text { base, forums, polls, tasks for managers and employees, a directory of users, } \\
\text { idea collectors, blogs. A distinctive feature of the service is gamification. The } \\
\text { network has a board of honor that is formed automatically based on various } \\
\text { criteria - from useful advice to brilliant ideas and important publications for } \\
\text { the corporation. The users can enter the social network using any device: } \\
\text { computer, smartphone or tablet. The developers offer two versions: the cloud } \\
\text { and the box system. The service is designed for large corporations; the } \\
\text { monthly fee starts with USD } 45 \text { per } 100 \text { users. The main disadvantages are: } \\
\text { only web version is available (no mobile application has been developed) and } \\
\text { an obsolete design of the late } 1990 \text { s }\end{array}$ \\
\hline
\end{tabular}

ments, user-friendly interface, and powerful communication system.

CSNs does not replace, but complement the existing electronic document management systems for approving, transmitting, and controlling the execution of orders, management, and financial accounting. They aim at solving problems and tasks beyond those established in existing corporate e-government systems. The figure shows how the corporate social network services correlate with business objectives on which they are focused and are identified with conventional human resources management systems (HRMS) (as compared with the subsystems of conventional HRMS).
Let us consider the use of Bitrix24 software in VO Oven corporation. Table 3 shows the effectiveness of this service as compared with the US CSN [9].

The functions of conventional HRMS identified in Table 3: 2.1 - analysis and administration of group and personal relationships; $2.4-$ socio-psychological diagnosis; 3.2 - information support of the HR management system; $3.4-$ employment management; 4.8 - assessment of existing personnel; 5.1 - staff training; 5.4 - professional and socio-psychological adaptation of employees. The HRMS functions are described in more detail in [5-8]. 
Having analyzed the effective areas of CSN application in American corporations and at VO OVEN corporation, one can conclude that an increase in the performance indices of the personnel as a result of applying the CSN in the corporation is explained by accelerating the personnel communication:
+ processing of information messages (reading and replying e-mail messages) (due to faster speed, and time reduction);

+ search and collection of information at a faster speed;

+ analysis, discussion, and communication while working together;

\section{Comparison of Capabilities in Terms of Raising Personnel IR Using CSN and Classical Internet Portal [4]}

\begin{tabular}{|c|c|}
\hline Classical Internet portal & $\mathrm{CSN}$ \\
\hline $\begin{array}{l}\text { Reflects a formal structure of corporation (not always), } \\
\text { without informal links taken into consideration }\end{array}$ & $\begin{array}{l}\text { Reflects real links in the organizational and managerial structure } \\
\text { of corporation and personnel, which facilitates raising IR }\end{array}$ \\
\hline The materials are published only by administrators & $\begin{array}{l}\text { The materials are published by all employees, which forms a } \\
\text { broader information field and contributes to raising IR }\end{array}$ \\
\hline $\begin{array}{l}\text { Selected content (only the most important information } \\
\text { that has been reviewed) is posted }\end{array}$ & $\begin{array}{l}\text { A large content forming a real framework of corporate knowledge } \\
\text { is posted. This approach facilitates raising IR }\end{array}$ \\
\hline $\begin{array}{l}\text { Centralized structure, slow, sanctioned "from above" } \\
\text { evolution }\end{array}$ & $\begin{array}{l}\text { Decentralized structure and natural evolution, which facilitates } \\
\text { raising IR }\end{array}$ \\
\hline Top-down communications & $\begin{array}{l}\text { Both top-down and bottom-up communications [4], which } \\
\text { ensures a feedback and facilitates raising IR of the personnel and } \\
\text { the corporation as a whole }\end{array}$ \\
\hline Terms of development and launch from 2 weeks & Terms of development and launch from 2 weeks \\
\hline Based on standard software like SharePoint & $\begin{array}{l}\text { Based on both standard and dynamic multifunctional SharePoint } \\
\text { or WebTycoon }\end{array}$ \\
\hline Costs from USD 4000 & Costs from USD 5000 \\
\hline Low motivation of employees & High motivation of employees, which facilitates raising IR \\
\hline
\end{tabular}

Table 2

Comparison of Effective Areas of CSN Application

Table 3 in American Corporations and at VO OVEN Ltd.

\begin{tabular}{|l|c|c|c|c|c|c|c|}
\hline \multirow{2}{*}{$\begin{array}{c}\text { Область } \\
\text { применения }\end{array}$} & \multirow{2}{*}{$\begin{array}{c}\text { Correspondence } \\
\text { to HRMS } \\
\text { functions }\end{array}$} & \multicolumn{2}{|c|}{$\begin{array}{c}\text { Time inputs, } \\
\% \text { weekly }\end{array}$} & \multicolumn{2}{c|}{$\begin{array}{c}\text { Increase } \\
\text { in performance, \% }\end{array}$} & \multicolumn{2}{c|}{$\begin{array}{c}\text { Time saved, } \\
\% \text { weekly }\end{array}$} \\
\cline { 4 - 9 } & $\mathrm{AC}$ & $\mathrm{UC}$ & $\mathrm{AC}$ & $\mathrm{UC}$ & $\mathrm{AC}$ & $\mathrm{UC}$ \\
\hline Reading and replying messages & 2.1 & 28 & 35 & $25-30$ & $30-40$ & $7.0-8.5$ & $10.5-14$ \\
Searching and collecting data & $2.4 ; 5.1$ & 19 & 15 & $30-35$ & $20-30$ & $5.5-6.5$ & $3.0-4.5$ \\
Communication and joint work & $2.1 ; 3.1 ; 3.4 ;$ & 14 & 10 & $25-35$ & $10-15$ & $3.5-5.0$ & $1.0-1.5$ \\
& $4.8 ; 5.1 ; 5.4$ & & & & & & \\
Specific tasks & $2.1 ; 3.1 ; 3.4 ;$ & 39 & 40 & $10-15$ & $40-50$ & $4.0-6.0$ & $16.0-20.0$ \\
Total & $5.1 ; 5.4$ & & & & & & \\
& & 100 & 100 & $20-25$ & $30.5-40$ & $20.0-25.0$ & $30.5-40.0$ \\
\hline
\end{tabular}

Note: AC - CSN performance indicators based on outlook of American corporations; UC - data based on example of ukrainian corporation $V O$ OVEN Ltd. 


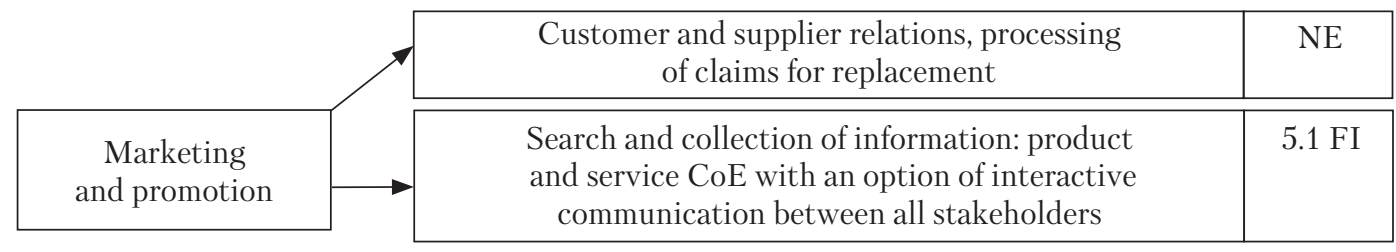

\begin{tabular}{|c|c|c|}
\hline & Common electronic mail and sms-service & $\mathrm{NE}$ \\
\hline \multirow{4}{*}{$\begin{array}{c}\text { Document flow } \\
\text { and communication }\end{array}$} & $\begin{array}{c}\text { Formation of common content, libraries, knowledge basis } \\
\text { by corporate business lines (saving of content } \\
\text { of key personnel who have left the corporation) }\end{array}$ & $5.1 \mathrm{FI}$ \\
\hline & \multirow{2}{*}{$\begin{array}{c}\text { Corporate communications, in-house } \mathrm{PR} \text {, competitions, } \\
\text { press, support programs, photo- and video reports, } \\
\text { corporate } \mathrm{TV} \text {, etc. }\end{array}$} & \multirow[t]{2}{*}{$\mathrm{NE}$} \\
\hline & & \\
\hline & $\begin{array}{c}\text { Joint work }- \text { seminars and workshops, forums, } \\
\text { online conferences, etc. }\end{array}$ & $5.1 \mathrm{PI}$ \\
\hline
\end{tabular}
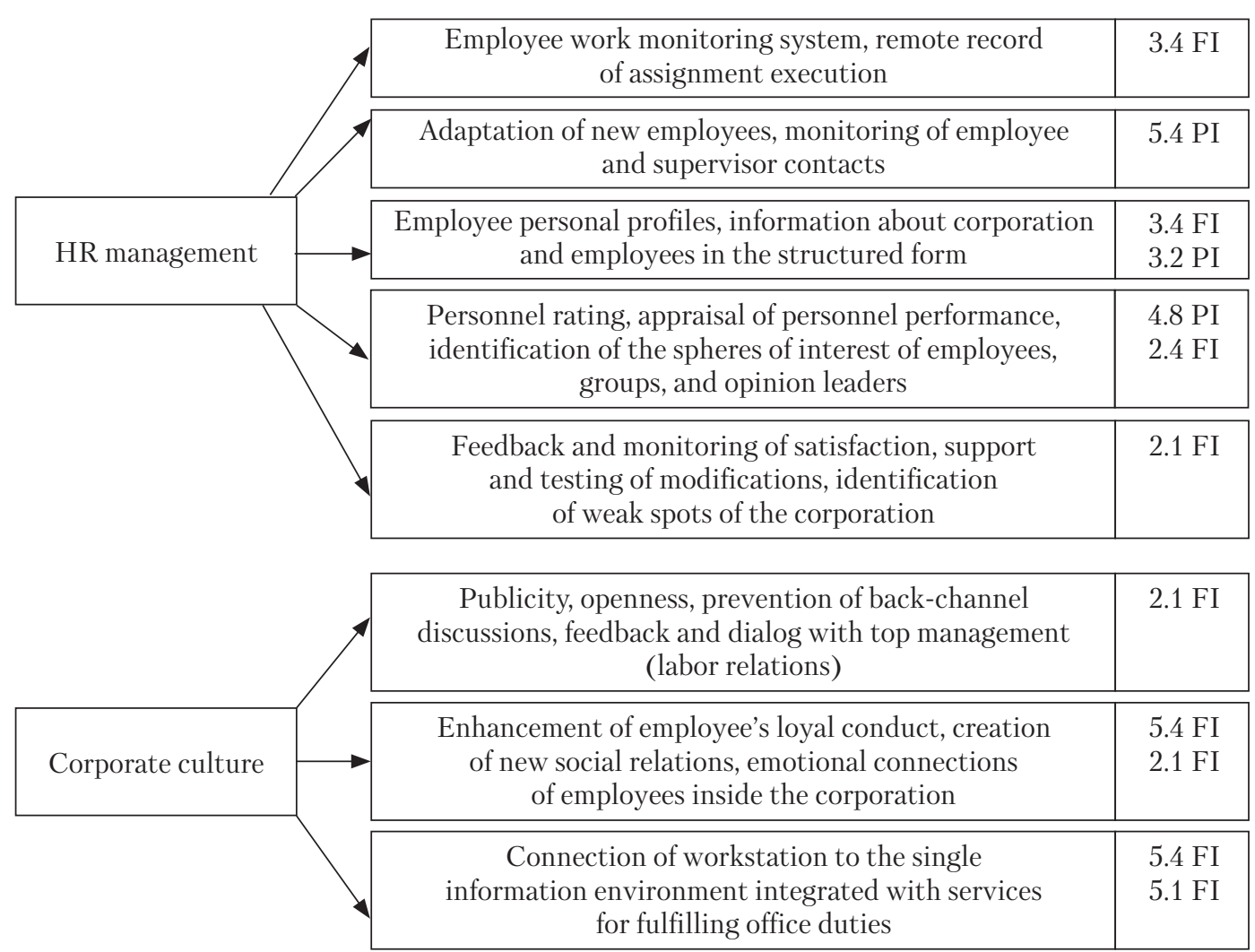

Fig. 1. CSN services in the corporation's system of business tasks and their identification with conventional HRMS: NE not enclosed in the conventional HRMS subsystems and functions; NI - not interoperable with conventional HRMS subsystems and functions; PI - partially interoperable with conventional HRMS subsystems and functions; FI - fragmentally interoperable with conventional HRMS subsystems and functions; CI - completely interoperable with conventional HRMS subsystems and functions. The right column shows the levels of identification of Bitrix24 software functions with conventional elements of HRMS of VO OVEN Ltd. 
Summary of Information Messages

of Bitrix24 (Buzz) Software at VO Oven Ltd.

for 2017 for the 1st Quarter of 2018

\begin{tabular}{|c|c|c|c|}
\hline \multirow{2}{*}{$\begin{array}{c}\text { Number } \\
\text { of } \\
\text { HRMS } \\
\text { function }\end{array}$} & \multirow{2}{*}{ HRMS functions } & \multicolumn{2}{|c|}{$\begin{array}{l}\text { Number of } \\
\text { messages, pcs }\end{array}$} \\
\hline & & 2017 & $\begin{array}{l}1^{\text {st }} \text { quarter } \\
\text { of } 2018\end{array}$ \\
\hline 3.1 & Documenting and accounting & - & 11 \\
\hline 3.2 & $\begin{array}{l}\text { Information support of HR re- } \\
\text { cord keeping system }\end{array}$ & 20 & - \\
\hline 4.6 & $\begin{array}{l}\text { Connections to outsourcing } \\
\text { agencies }\end{array}$ & 2 & - \\
\hline 5.1 & $\begin{array}{l}\text { Technical and economical trai- } \\
\text { ning }\end{array}$ & 9 & 15 \\
\hline 5.2 & $\begin{array}{l}\text { Information support of HR, } \\
\text { implementation of workflows }\end{array}$ & 359 & 77 \\
\hline 5.3 & $\begin{array}{l}\text { Management, planning, and cont- } \\
\text { rol of professional life }\end{array}$ & - & 1 \\
\hline 6.2 & Development of salary system & - & 3 \\
\hline 6.3 & Labor incentive management & - & 3 \\
\hline 6.4 & $\begin{array}{l}\text { Development of forms of holding } \\
\text { share in profit and capital }\end{array}$ & - & 1 \\
\hline 6.5 & Use of forms of moral incentives & 23 & 1 \\
\hline 8.3 & $\begin{array}{l}\text { Development of culture and phy- } \\
\text { sical training }\end{array}$ & 15 & 1 \\
\hline 9.1 & $\begin{array}{l}\text { Analysis of organizational struc- } \\
\text { ture of management }\end{array}$ & 24 & 6 \\
\hline 9.2 & $\begin{array}{l}\text { Drafting and formation of new } \\
\text { organizational structure }\end{array}$ & 5 & 4 \\
\hline & Total & 457 & 123 \\
\hline
\end{tabular}

+ increase in performance of teamwork (due to communication and teamwork;

+ fulfillment of specific tasks.

A comparative analysis of the Bitrix 24 services with the conventional elements of $V O O V E N$ corporation's HRMS has showed that there is a lack of interoperability between the services and the integrated HRMS; some subsystems and functions do not actually support the corresponding services because the CSN is designed for a general purpose of improving the HRMS systems and realizing its subsystems and functions.

Information messages of Bitrix $24 \mathrm{CSN}$ of $\mathrm{VO}$ OVEN Ltd. for 2017 and in more detail for the first quarter of 2018 have been analyzed in order to form a material for analyzing the implementation of the HRMS system in this CSN (Table 4).

Having analyzed summary data of Table 4, one can conclude that buzz information messages do not sufficiently cover the functions of the HRMS subsystem. Most of these messages are related to workflow and operating process: the introduction of new technologies, devices, software; information about competitors and customers; investment projects; opening / closing of sales; changes in prices; industrial solutions; useful information for industry managers; useful information on various issues (operation of site, portal, devices; 1C, educational literature, leisure, connection and configuration of devices); reports on the works done by different departments; presentations; technical and econommical issues; self-development and learning.

At the same time, some issues that the HRMS is intended to implement in the CSN are poorly developed; the subsystems of working conditions, labor relations, planning, forecasting, HR marketing, and legal services are not considered at all [5].

Accordingly, it is advisable to improve the Bitrix24 software system in line with the HRMS development trends, for example, to introduce the functions for staff information support and for the implementation of technical and economic processes into the conventional HRMS.

It is also necessary to expand the Bitrix 24 software features regarding the HRMS functions (for example, "labor conflicts", etc. [5]) that have not been taken into consideration.

The promising areas for improving the Bitrix24 software are as follows:

1. Development of services in terms of expanding them in accordance with the HRMS subsystems and functions.

2. Improvement of the interface in order to harmonize it with the HRMS functions (the formation of separate sections that now are presented mixed up, for example, scandals, sports, cultural chronicle, and social security).

3. Ideally, most of the HRMS functions [5] should be incorporated in the Bitrix 24 software. 
Hence, having made an analysis of Bitrix24 software application in VO OVEN corporation, one can conclude that not all CSN services in the organization's system of business targets have been taken into account in the subsystems and functions of conventional HRMS. And those enclosed are realized partially, fragmentary or periodically. It is necessary to introduce a new function that will reflect the staff information support and the implementation of technical and economic processes in the current conditions of CSN development.

Further research in the field of HRSM, includ- ing for $V O$ OVEN corporation, has to aim at understanding the theory of personnel IR, its role and reflection in the organizational and management structure of corporations, which should be formed taking into account the socialization of personnel and be reflected in corporate systems. Also, to ensure an adequate perception of digital technologies at industrial corporations of Ukraine, these corporations need to have qualified personnel possessing digital skills and competences. One of the options for the development of such capacity is the use of CSN.

\title{
REFERENCES
}

1. Acimov, S.O. Design of influence of внутрифирменных communications in a corporate social network on development of competenses of employees of enterprise [in Russian]. URL: http://www.dissercat.com/content/modelirovanievliyaniya-vnutrifirmennykh-kommunikatsii-v-korporativnoi-sotsialnoi-seti-na-ra\#ixzz5B8GS8J4o. (Last accessed: 12.06.2018).

2. Overview of corporate social networks: we compare features and functionality [in Russian]. URL: https://www. pravda.ru/navigator/obzor-korporativnykh-sotsial-nykh-setei.html. (Last accessed: 12.06.2018).

3. Corporate social networks [in Russian]. URL: http://www.spbnet.ru/solutions_and_services/intranet/networks. html. (Last accessed: 14.06.2018).

4. Gaponov, O. S., Kites, I. A., Zacablucovsciy, E. V. (2015). The Corporate social networks in the modern management of organization. Management in Russia and abroad, 1, 79-88 [in Russian].

5. Dyuzhev, V. G., Suslikov, S. V., Boichenko, O. I. (2017). Influence is on innovative favourableness of descriptions of control system by a personnel. Scientific and production magazine "BUSINESS-NAVIGATOR", 4-1(43), 138-142 [in Russian].

6. Boichenko, O. I. (2018). Innovations on the example of the Ukrainian industrial company. Announcer. Kharkiv national university of the name Carazina V.N. KNU. Series the "International relations. Economy. Country-specific studies. Tourism" Producing 7, 80-86 [in Russian].

7. Dyuzhev, V. G., Boichenko, O. I. (2018). Innovative receptivity of market for industry electroenergy. Electronic professional magazine "East Cepona: economy, business and management", 1(12). URL: http://www.easterneurope-ebm.in.ua/ 12-2018 [in Ukrainian]. (Last accessed: 18.06.2018).

8. Dyuzhev, V. G., Boichenko, O. I. (2017). Increase of innovative receptivity of personnel of commercial service of enterprises industrially automats. An announcer NTU is the "Kharkov polytechnic institute" (economic sciences). Collection of scientific works, 45(1266), 42-46 [in Ukrainian].

9. The social economy: Unlocking value and productivity through social technologies. URL: https://www.mckinsey. com/industries/high-tech/our-insights/the-social-economy. (Last accessed: 19.06.2018).

Received 11.06.18

\author{
В.Г. Дюжев, О.І. Бойченко \\ Національний технічний університет \\ «Харківський політехнічний інститут», \\ вул. Кирпичова, 2, Харків, 61002, Україна, \\ +380501842823, olegmet3000@ukr.net

ВПЛИВ НА ІННОВАЦІЙНУ СПРИЙНЯТЛИВІСТЬ ПЕРСОНАЛУ
КОРПОРАТИВНИХ СОЦІАЛЬНИХ МЕРЕЖ, НА ПРИКЛАДІ
ПРОГРАМНОГО ЗАБЕЗПЕЧЕННЯ ВІТRІХ 24, В КОМПАНІЇ ТОВ «ВО ОВЕН»

Вступ. Актуальним питанням підвищення інноваційної сприйнятливості (IC) персоналу є використання внутрішньофірмових корпоративних соціальних мереж (КСМ).

Проблематика. На сьогодні в Україні відбувається активне обговорення проблем цифрових трансформацій економіки, а також важливості цифрових ініціатив і наукових досліджень у цій галузі, про що свідчить прийнята у січні 
2018 року Концепція розвитку цифрової економіки та суспільства України на 2018-2020 рр. та відповідний план заходів щодо реалізації цієї Концепції (затверджений Кабінетом Міністрів України). Теоретичні та практичні питання аналізу впливу внутрішньофірмових комунікацій у КСМ на розвиток компетенцій та IC співробітників підприємств, на сьогодні, опрацьовані не повною мірою.

Мета. Визначення тенденцій і закономірностей впливу КСМ на IC персоналу на прикладі ПЗ Bitrix 24 в компанії ТОВ «ВО Овен».

Матеріали й методи. Методи порівняльного аналізу роботи вітчизняних та закордонних КСМ в Україні та світі; аналіз використання ПЗ Bitrix 24 в українській компанії.

Результати. Показано можливості підвищення IC персоналу при використанні КСМ і класичного інтернетпорталу. Проаналізовано сервіси КСМ в системі бізнес-завдань організації та їх ідентифікація з традиційними системами управління персоналом (СУП). Приведено порівняння ефективних сфер застосування КСМ в американських компаніях і в ТОВ «ВО ОВЕН» (Україна). А також наведено підсумкові дані інформаційних повідомлень ПЗ Bitrix 24 (жива стрічка) в компанії ТОВ «ВО Овен» за 2017 р. і за І квартал 2018 р. За результатами дослідження введено нову функцію СУП, яка показуватиме інформаційне забезпечення персоналу, реалізацію техніко-економічних процесів для розвитку КСМ в нинішніх умовах.

Висновки. Для забезпечення адекватного сприйняття цифрових технологій на промислових підприємствах $\mathrm{У}_{\text {к- }}$ раїни потрібні кваліфіковані кадри, які володіють цифровими навичками та компетенціями. Одним з варіантів розвитку таких компетенцій є використання КСМ.

Ключові слова: інноваційна сприйнятливість, корпоративні соціальні мережі, Bitrix 24.

\author{
В.Г. Дюжев, О.И. Бойченко \\ Национальный технический университет \\ «Харьковский политехнический институт», \\ ул. Кирпичева, 2, Харьков, 61002, Украина, \\ +380 50184 2823, olegmet3000@ukr.net

\section{ВЛИЯНИЕ НА ИННОВАЦИОННУЮ ВОСПРИИМЧИВОСТЬ ПЕРСОНАЛА КОРПОРАТИВНЫХ СОЦИАЛЬНЫХ СЕТЕЙ, НА ПРИМЕРЕ ПРОГРАМНОГО ОБЕСПЕЧЕНИЯ ВITRIX 24, В КОМПАНИИ ООО «ВО ОВЕН»»}

Введение. Актуальным вопросом повышения инновационной восприимчивости (ИВ) персонала является использование внутрифирменных корпоративных социальных сетей (КСС).

Проблематика. На сегодня в Украине происходит активное обсуждение проблем цифровых трансформаций экономики, а также важность цифровых инициатив и научных исследований в этой отрасли, про что свидетельствует принятая в январе 2018 года Концепция развития цифровой экономики и общества Украины на 2018-2020 гг. и соответствующий план мероприятий для реализации этой Концепции (утвержденный Кабинетом Министров Украины). Теоретические и практические вопросы анализа влияния внутрифирменных коммуникаций в КСС на развитие компетенций и ИВ сотрудников предприятий, на сегодня, проработаны недостаточно полно.

Цель. Определение тенденций и закономерностей влияния КСС на ИВ персонала на примере ПО Bitrix24 в компании ООО «ВО Овен».

Материалы и методы. Методы сравнительного анализа работы отечественных и зарубежных КСС в Украине и мире; анализ использования ПО Вitrix24 в украинской компании.

Результаты. Показано возможности повышения ИВ персонала при использовании КСС и классического интернет-портала. Проанализировано сервисы КСС в системе бизнес-задач организации и их идентификация с традиционными системами управления персоналом (СУП). Приведено сравнение эффективных областей применения КСС в американских компаниях и в ООО «ВО ОВЕН» (Украина). А также представлены итоговые данные информационных сообщений ПО Bitrix 24 (живая лента) в компании ООО «ВО Овен» за 2017 г. и за I квартал 2018 г. По результатам исследования введена новая функция СУП, которая будет отражать информационное обеспечение персонала, реализацию технико-экономических процессов для развития КСС в нынешних условиях.

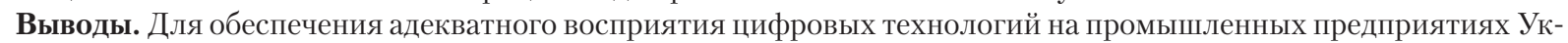
раины необходимы квалифицированные кадры, которые владеют цифровыми навыками и компетенциями. Одним из вариантов развития таких компетенций является использование КСС.

Ключевые слова: инновационная восприимчивость, корпоративные социальные сети, Bitrix 24. 